\title{
Epidemiological and Temporal Analysis of Leprosy in a Brazilian Endemic State
}

Karen Krystine Gonçalves de Brito ${ }^{1}$, Smalyanna Sgren da Costa Andrade ${ }^{1}$, Emanuelle Malzac Freire Santana², Suellen Duarte de Oliveira Matos' Iraktânia Vitorino Diniz² ${ }^{2}$ Elizabeth Souza Silva de Aguiar1, Kamila Nethielly Souza Leite ${ }^{2}$, Valéria Peixoto Bezerra ${ }^{4}$, Mirian Alves da Silva ${ }^{3}$, Ana Paula Marques Andrade de Souza ${ }^{3}$, Simone Helena dos Santos Oliveira ${ }^{4}$, Maria Júlia Guimarães Oliveira Soares ${ }^{4}$

\section{Abstract}

Background: Leprosy is endemic in Brazil, while the number of diagnosed cases of the disease has made considerable decrease since the implementation of treatment with multidrug therapy. The objective of this research, analyze time trends in sociodemographic and clinicalepidemiological profile of leprosy in Paraíba, in the 2001-2011 period, and identify differences between the epidemiological trends within the period.

Methods: Epidemiological study of time, retrospective and documentary based series, produced using secondary data and Notification Diseases Information System.

Results: They evaluated data on 10.476 Sheets Notification single, between the years 2001-2011, based on descriptive and inferential statistics. The results showed statistically significant differences between the two areas evaluated time, starting with the suggestive reduction of $42.7 \%$ of cases in P2 (2007-2011), although this timeline, the clinical characterization refers to the most serious states or late leprosy.

Conclusion: Leprosy remains a relevant epidemiological dilemma, especially in view of the increase in the proportion of MB cases, glimpsed for the period studied.
1 Doctoral student in the Graduate Program in Nursing at the Federal University of Paraíba, João Pessoa, Paraíba, Brazil.

2 Masters student in the Graduate Program in Nursing at the Federal University of Paraíba, João Pessoa, Paraíba, Brazil.

3 Professor PhD, Department of Clinical Nursing of the Federal University of Paraíba, João Pessoa, Paraíba, Brazil.

4 Professor PhD in the Graduate Program in Nursing at the Federal University of Paraíba, João Pessoa, Paraíba, Brazil.

\section{Contact information:}

Karen Krystine Gonçalves de Brito.

Address: Severina Alves de Lima, $n^{\circ} 74$ CEP: 58079-240. Funcionários II/João Pessoa/Paraíba.

Tel: +55 83999075034 .

”" karen_enf@yahoo.com.br 


\section{Introduction}

Leprosy continues to be regarded as an important public health problem, although the number of diagnosed cases of the disease has presented considerable decrease since the implementation of treatment with multidrug therapy. The pathological characteristics of high infectivity and low pathogenicity, its crippling power and potential for maintaining the transmission chain are pillar to the epidemiological current dilemmas.

The disease registered a prevalence of 180.464 cases in 103 countries worldwide, at the end of the first quarter of 2014, while in the year 2013, 215.557 new cases were detected (excluding the small number of cases in Europe) and in Brazil 31.044 cases were detected [1].

The distribution of leprosy in the country varies according to the geopolitical regions, considering the different aspects found in these spaces, such as socio-economic, cultural, educational and sanitary inequalities. In this way, high transmission areas of the disease in Brazil are concentrated in the North, Northeast and Center-West [2].

As regards epidemiological surveillance, the leprosy control activities should be constant strategies and should be kept over the years [3], but its late diagnosis is considered one of the main factors that interfere in the effective control of the disease, due to its transmission from infectious patients without treatment.

Elected aspects as well as contributing to the transmission chain maintenance are the long incubation period of the bacillus (from five to seven years), the chronicity of the clinical manifestations, the cases of hidden prevalence, the operational difficulty of health services, the ignorance by the population in relation to clinical manifestations and prejudice [4-5].

Inserted in this context, the State of Paraíba, located in the Northeast region of Brazil, appears as a cluster of leprosy transmission and locus of epidemiological importance for studies aimed at identi- fying the demographic and clinical-epidemiological trend of cases over the years, being sure that these cases can help to elucidate the maintenance of contagion sources on population.

In this sense, there is the relevance of this study, which aims to analyze the temporal trends in sociodemographic and clinical-epidemiological profile of leprosy in Paraíba, in the 2001-2011 period, and identify differences between the epidemiological trends within the period.

This temporal delimitation is justified because of the programs launched by the Ministry of Health $(\mathrm{MOH})$ which established the goal of eliminating the disease (Strategic Plan 2000-2005, 2006-2010) [6-7] and that have not been successful.

\section{Methods}

Epidemiological study of temporal retrospective series and documentary basis, using secondary data of the Diseases Information System and Notification (SINAN) of the Department of Health (SES) of Paraiba. Based on the database, there were identified 10,476 Individual Sheets of Leprosy Cases Notification recorded from 2001 to 2011, distributed among the municipalities of the State.

Then, it was performed the database refinement to identify the variables of interest, such as: age group, gender, race/ethnicity, education, number of lesions and affected nerves (none, one, between 2-3, 4 or more), clinical form of the disease (indeterminate, tuberculoid, dimorphic or lepromatous), operational classification (paucibacillary or multibacillary), degree of disability at diagnosis $(0,1$ and II grades), bacilloscopy results (positive or negative) and type of discharge (cure, transfer, death, abandonment and misdiagnosis).

Data was subdivided into two periods called P1 and P2, being P1 from 2001 to 2006 and P2 from 2007 to 2011. This subdivision allowed facilitating comparison between periods, in addition to evaluating the data oscillations. 
Data was decoded according to the data dictionary of SINAN Net (version 4.0), being built a new database in the Microsoft Office Excel program. Completed this step, data was compiled for descriptive analysis in the Statistical Package for Social Science version 18.0 software, through descriptive statistics with absolute frequencies and percentages. For association between variables, it was used inferential statistics, through Pearson Chi-square, Fisher Exact, and t Student tests for average differences, considering the level of significance of $5 \%$ $(p \leq 0.05)$.

The data collection period, including identification of individual sheets of notification, refinement, decoding and compilation of statistical program variables occurred between May and August 2013. This study was approved by the Research Ethics Committee of the Health Sciences Center/Federal University of Paraiba, with Protocol No 203.485, CAAE 11076312.1.0000.5188, in accordance to the $466 / 12$ Resolution of the National Council of Health [8].

We also point out that the results presented in this article are derived from the master's dissertation "Epidemiological and temporal analysis of leprosy in Paraíba", presented to the Post-Graduate Program in Nursing at the Federal University of Paraíba, by the main author.

\section{Results}

Of the total of 10.476 reported cases of leprosy in the SINAN were identified 6,161 cases in P1 (20012006) and 4.315 cases in P2 (2007-2011), representing a reduction of $42.7 \%$ of cases among those periods.

In the socio-demographic profile of the cases there was an association ( $p<0.05$ ) between the selected variables (age group, gender, race, education), but this profile differs between the temporal P1 and P2 (Table 1) records.

Among the variables presented, the age stands out in the periods for presenting significant fre-
Table 1. Sociodemographic characterization of leprosy cases for temporal records (P1 and P2). Paraíba, 2001-2011 ( $n=10,476)$.

\begin{tabular}{|c|c|c|c|c|c|}
\hline \multirow{2}{*}{ Variables } & \multicolumn{2}{|c|}{ P1 } & \multicolumn{2}{|c|}{ P2 } & \multirow{2}{*}{$\begin{array}{c}\text { Significance } \\
\text { (p-value) }\end{array}$} \\
\hline & $n$ & $\%$ & $n$ & $\%$ & \\
\hline $\begin{array}{l}\text { Age } \\
\text { average } \pm \\
\text { dp }\end{array}$ & \multicolumn{2}{|c|}{$40.20 \pm 19.64$} & \multicolumn{2}{|c|}{$43.07 \pm 19.27$} & $<0.0001^{3}$ \\
\hline \multicolumn{6}{|l|}{ Age group } \\
\hline $\begin{array}{l}<15 \text { years } \\
\text { old }\end{array}$ & 510 & 8.28 & 276 & 6.40 & \multirow{6}{*}{$<0.0001^{1}$} \\
\hline $\begin{array}{l}15-19 \\
\text { years old }\end{array}$ & 548 & 8.89 & 228 & 5.28 & \\
\hline $\begin{array}{l}20-29 \\
\text { years old }\end{array}$ & 1137 & 18.45 & 718 & 16.64 & \\
\hline $\begin{array}{l}30-39 \\
\text { years old }\end{array}$ & 949 & 15.40 & 740 & 17.15 & \\
\hline $\begin{array}{l}40-49 \\
\text { years old }\end{array}$ & 988 & 16.04 & 708 & 16.41 & \\
\hline $\begin{array}{l}50 \text { years } \\
\text { old or more }\end{array}$ & 2029 & 32.93 & 1645 & 38.12 & \\
\hline \multicolumn{6}{|l|}{ Gender } \\
\hline Masculine & 2960 & 48.04 & 2201 & 51.01 & \multirow{2}{*}{$0.0029^{1}$} \\
\hline Feminine & 3201 & 51.96 & 2114 & 48.99 & \\
\hline \multicolumn{6}{|l|}{ Race } \\
\hline White & 1499 & 24.33 & 1243 & 28.81 & \multirow{6}{*}{$<0.0001^{2}$} \\
\hline Black & 504 & 8.18 & 475 & 11.01 & \\
\hline Yellow & 111 & 1.80 & 55 & 1.27 & \\
\hline $\begin{array}{l}\text { Medium } \\
\text { brown }\end{array}$ & 2246 & 36.46 & 2337 & 54.16 & \\
\hline Indigenous & 3 & 0.05 & 21 & 0.49 & \\
\hline $\begin{array}{l}\text { Without } \\
\text { identif./ } \\
\text { Ignored (*) }\end{array}$ & 1798 & 29.18 & 184 & 4.26 & \\
\hline \multicolumn{6}{|l|}{ Education } \\
\hline Illiterate & - & - & 462 & 10.71 & \multirow{5}{*}{$<0.0001^{2}$} \\
\hline $\begin{array}{l}\text { Elementary } \\
\text { School }\end{array}$ & 4845 & 78.63 & 2207 & 51.14 & \\
\hline High school & 483 & 7.84 & 516 & 11.96 & \\
\hline $\begin{array}{l}\text { Higher } \\
\text { education }\end{array}$ & - & - & 147 & 3.41 & \\
\hline $\begin{array}{l}\text { Without } \\
\text { identif./ } \\
\text { Ignored (*) }\end{array}$ & 833 & 13.52 & 983 & 22.78 & \\
\hline
\end{tabular}

Source: SES/PB data, 2014. 1: Chi-square Association Test. 2: Fisher's Exact Test. 3: T-test for average difference. *: The statistical tests did not consider this information. 
quency in number of cases in all age groups economically active. The age group between 20 and 29 years old has increased number of cases (1.137) in P1, while between 30 and 39 years old (740) stands out in $\mathrm{P} 2$.

The age group up to 19 years evolves with featured in number of cases in P1 (total of $1.058 \mathrm{ca}$ ses) with significant decline in P2 (504 total cases), occurring a reverse evolution of the number of cases in the age group of 50 years old or more in the period.

The education variable presents eloquent changes in its patterns, in which, in $\mathrm{P} 2$, the reduction of cases with low education (illiterate and primary school) compared to P1, while still totaling majority (61.8\%).

Allusive to the clinical-epidemiological profile (Table 2), were observed statistically significant differences ( $p$-values $<0.05$ ) for the temporal cutouts P1 and P2 as for the average number of injuries, when there is an average of 3.5 lesions in P1 and 5.5 lesions in P2, representing an increase of $57.1 \%$ between the periods in this variable (Table 2 ).

Analyzed according to important scheme for the operational classification of the Ministry of Health, it is clear that for the P1 period, $74.6 \%$ of the cases present up to 5 lesions; while in the P2 period, this

Table 2. Clinical and epidemiological characterization of leprosy cases for temporal records (P1 and P2). Paraíba, 2001-2011 (n $=10,476)$.

\begin{tabular}{|c|c|c|c|c|c|}
\hline \multirow{2}{*}{ Variables } & \multicolumn{2}{|c|}{ P1 } & \multicolumn{2}{|c|}{ P2 } & \multirow{2}{*}{$\begin{array}{c}\text { Significance } \\
\text { (p-value) }\end{array}$} \\
\hline & $\mathrm{n}$ & $\%$ & $\mathrm{n}$ & $\%$ & \\
\hline \multirow{2}{*}{$\begin{array}{l}\text { Number of } \\
\text { injuries }\end{array}$} & \multicolumn{2}{|c|}{ average $\pm d p^{*}$} & \multicolumn{2}{|c|}{ average $\pm d p^{*}$} & \multirow{2}{*}{$<0.0001^{3}$} \\
\hline & \multicolumn{2}{|c|}{$3.52 \pm 6.26$} & \multicolumn{2}{|c|}{$5.57 \pm 7.66$} & \\
\hline None & 1638 & 26.59 & 111 & 2.57 & \\
\hline One to five & 2960 & 48.04 & 2532 & 58.68 & \\
\hline $\begin{array}{l}\text { More than } \\
\text { five }\end{array}$ & 1190 & 19.32 & 1465 & 33.95 & $<0.0001^{1}$ \\
\hline $\begin{array}{l}\text { Without } \\
\text { identif./ } \\
\text { Ignored* }\end{array}$ & 373 & 6.05 & 207 & 4.80 & \\
\hline
\end{tabular}

\begin{tabular}{|c|c|c|c|c|c|}
\hline \multirow{2}{*}{ Variables } & \multicolumn{2}{|c|}{ P1 } & \multicolumn{2}{|c|}{ P2 } & \multirow{2}{*}{$\begin{array}{c}\text { Significanc } \\
\text { (p-value) }\end{array}$} \\
\hline & $n$ & $\%$ & $n$ & $\%$ & \\
\hline \multirow{2}{*}{$\begin{array}{l}\text { Number of } \\
\text { affected } \\
\text { nerves }\end{array}$} & \multicolumn{2}{|c|}{ average $\pm d p^{*}$} & \multicolumn{2}{|c|}{ average $\pm d p^{*}$} & \multirow{2}{*}{$<0.0001^{3}$} \\
\hline & \multicolumn{2}{|c|}{$0.44 \pm 1.09$} & \multicolumn{2}{|c|}{$0.78 \pm 1.53$} & \\
\hline None & 4544 & 73.75 & 1254 & 29.06 & \multirow{5}{*}{$<0.0001^{1}$} \\
\hline One & 573 & 9.30 & 272 & 6.30 & \\
\hline $\begin{array}{l}\text { Between } 2 \\
\text { and } 3\end{array}$ & 503 & 8.16 & 264 & 6.12 & \\
\hline 4 or + & 168 & 2.73 & 109 & 2.53 & \\
\hline $\begin{array}{l}\text { Without } \\
\text { identif./ } \\
\text { Ignored* }\end{array}$ & 373 & 6.05 & 2416 & 55.99 & \\
\hline
\end{tabular}

Disability evaluation

\begin{tabular}{|c|c|c|c|c|c|}
\hline Grade zero & - & - & 1814 & 42.04 & \\
\hline Grade I & 2529 & 41.05 & 440 & 10.20 & \\
\hline Grade II & 270 & 4.38 & 169 & 3.92 & $<0.0001^{2}$ \\
\hline $\begin{array}{l}\text { Without } \\
\text { identif./ } \\
\text { Ignored* }\end{array}$ & 3362 & 54.57 & 1892 & 43.85 & \\
\hline
\end{tabular}

Operating rating

\begin{tabular}{|c|c|c|c|c|c|}
\hline Paucibacillar & 3343 & 54.26 & 2051 & 47.53 & \\
\hline Multibacillar & 2789 & 45.27 & 2260 & 52.38 & \\
\hline $\begin{array}{l}\text { Without } \\
\text { identif./ } \\
\text { lgnored* }\end{array}$ & 29 & 0.47 & 4 & 0.09 & $<0.0001^{1}$ \\
\hline
\end{tabular}

\begin{tabular}{l|c|c|c|c|c|}
\hline $\begin{array}{l}\text { Clinical form } \\
\text { Undeter- }\end{array}$ & 1419 & 23.03 & 682 & 15.80 & \\
$\begin{array}{l}\text { mined } \\
\text { Tuberculoid }\end{array}$ & 1952 & 31.69 & 990 & 22.95 & \\
\hline $\begin{array}{l}\text { Dimorphic } \\
\text { Leproma- }\end{array}$ & 1660 & 26.94 & 1087 & 25.20 & \\
$\begin{array}{l}\text { Lous } \\
\text { tous }\end{array}$ & 989 & 16.05 & 649 & 15.04 & $<0.0001^{1}$ \\
$\begin{array}{l}\text { Without } \\
\text { identif./ } \\
\text { lgnored* }\end{array}$ & 141 & 2.29 & 907 & 21.01 & \\
\hline
\end{tabular}

\begin{tabular}{|c|c|c|c|c|c|}
\hline \multicolumn{6}{|c|}{ Bacilloscopy } \\
\hline Positive & 748 & 12.14 & 576 & 13.35 & \multirow{3}{*}{$<0.0001^{1}$} \\
\hline Negative & 1367 & 22.19 & 801 & 18.56 & \\
\hline $\begin{array}{l}\text { Without } \\
\text { identif./ } \\
\text { lgnored* }\end{array}$ & 4046 & 65.67 & 2938 & 68.09 & \\
\hline
\end{tabular}

Source: SES data, 2014. 1: Chi-square Association Test.

2: Fisher's Exact Test. ${ }^{3}$ : T-test for average difference.

*: The statistical tests did not consider this information. 
value decreases to $61.2 \%$, which represents $21.8 \%$ in reduction of cases, thus the cases of more than 5 lesions increased significantly $(75.7 \%)$ in $\mathrm{P} 2$.

The disability assessment at diagnosis is noteworthy, with a view to its epidemiological importance for the leprosy control program in the State, verifying that P1 records 373 cases (54.5\%) and P2 records 2416 cases (43.8\%) of disability unidentified or ignored. There are approximately 2 times fewer cases with grade I or II of incapacity.

Concerning the neural damage, the number of cases without affected nerves demand attention both in P1 (4.544 cases) and P2 (1.254 cases). Although the number of cases has decreased considerably for $\mathrm{P} 2$, there was an increase among the neglected data (not rated/ignored).

The analysis of the characteristics on a clinical and bacilloscopy form shows the increased number of cases with ignored/not reported information in P2.

\section{Discussion}

The results show statistically significant differences between the two timelines evaluated, starting with the suggestive reduction of $42.7 \%$ of cases in $\mathrm{P} 2$ (2007-2011). In general, in P1 were recorded more cases of leprosy, though with less severe clinical features, i.e. related to the paucibacillar aspects of the disease. On the other hand, for P2, it was observed clinical characterization compatible with more severe or late states of leprosy (increase of $75.7 \%$ in cases with more than 5 injuries, prevalence of multibacillary cases, namely: borderline and lepromatous).

It should be mentioned that the number of cases recorded in P2 presented less disabilities at diagnosis (adding up the values for grade I and grade II, there were 3.2 times less disabilities compared to P1), however this information shows negligence in filling neurological evaluation records of these cases, preventing an analysis of the evolution of this variable cases.
The implementation of multidrug therapy may be considered in the elimination of leprosy, and this goal has been achieved by many countries. However, the disease remains endemic at the present time, by the prevalence of cases in epidemiological clusters situated basically in tropical regions and in developing regions.

After more than 30 years of implementation of this treatment, discussions are still being carried out involving actions, innovations and strategies that extend the possibilities for effectiveness of the leprosy's elimination goals as a public health problem in endemic countries, since the maintenance of the methods employed for more than 25 years has not been sufficient for the problem resolution [9-10].

Discussions regard the maintenance of the endemic disease, its possible shortcomings, setbacks and tiny advances. The study shows that enthusiasm inserted in multidrug therapy overcame caution about its evidence leading to accreditation of the disease elimination, repeatedly delayed. This mistake resulted in relaxation and contributed to the neglect of leprosy as a public health problem [11].

The study on the occurrence of leprosy involving 148 countries highlights differences between the findings concerning the prevalence and incidence rates of the disease over the years from 2000 to 2010. Several factors can be attributed to the permanence of the endemic, though, questions directed to transmission mechanisms, intracellular reproduction metabolism and immune response to human infection are mentioned as important means of investigation, for the formulation of more effective interventions in public health [5].

Yet this perspective, research indicates that subclinical infection [12] and the continuous surveillance of contacts [13], can be the key to solving the longterm leprosy incidence.

The reduction in the number of leprosy cases presented in this study follows trend presented in the regions of Brazil [14] and endemic countries in 
the world [15], supposedly influenced by decentralization and recommendation of settings for goals and plans specific to each region, both established as strategies by World Health Organization [7, 16].

In Brazil, major changes in attention to public health that occurred from 2007-2010, as investment in primary care-oriented decentralized health, the encouragement in the control of disease in children under 15 years old and contacts monitoring, were important strategies to reach the goal of leprosy control [17]. These changes corroborate the number of overall cases, and in children under 15 years old, found by this study.

The decrease in the number of leprosy cases in the State over the period studied should not be regarded as promising, since the transmission chain remains with the presentation of clinical forms considered as a source of spread of the disease.

The significant difference compared to P1 ( $p<$ $0.05)$ regarding the clinical forms, favors the permanence of endemic disease in the region, since infectious cases (multibacillary) are considered as a source of infection, which reflect an ineffectiveness of public actions of case detection.

Despite the reduction in cases of leprosy in the 2007-2011 period (P2) with physical disabilities assessed at the time of diagnosis, the percentile of neglect on this information is misplaced, precludes the possibility of claims and/or assumptions about the phenomenon.

This minimization of cases reinforces the idea of a hidden endemic, providing decrease in the number of cases accounted for P2, and refers us to the view that the fight against leprosy structure is working statically. The reality described converges with other published studies [18-21]

By affecting mainly cutaneous cells and peripheral nerves, leprosy has high incapacitating potential, making it the object of research and social concern. The most aggressive forms of the disease, borderline and lepromatous, are grouped in multibacillary classification, established as those cases where the individual presents more than five skin lesions or with positive bacilloscopy (in this case, regardless of the number of injuries) [22]

Multibacillary patients are responsible for the transmission of the disease, and are about 4 (four) times more likely to develop into physical disability [23]. Therefore, early diagnosis favors the increase of chances to evolve without appearance of disabilities and decreases the spread of the bacillus.

The studied sample is mainly limited to negligence in completing the reporting forms. What is observed in the results is that the most important information from the epidemiological point of view, with emphasis on the degree of disability, are not filled in by professionals and, therefore, do not constitute the consolidated information delivered to the Brazilian Ministry of Health.

On data reliability, few studies have proposed to study the SINAN for leprosy, but those which did it found flaws similar to those presented in this study, showing them in the assessment of the disability degree [19, 24-25]. The fragility of the information system can be related to the filling performed by professionals, the data processing, its inadequate typing or even neglect and lack of variables filling [19], but this is not the study object of analysis.

Changes in leprosy magnitude in endemic areas, probably, are only apparent after many years of work, that's why it's so important to monitor its progress [5]. However, improvements in health information systems are needed to avoid the weaknesses in these records that limit the achievement of other studies.

\section{Conclusion}

The results found in this research converge to reduction in the number of leprosy cases, however, with epidemiological characteristics related to more severe stages of the disease. The presence of hidden endemic in the region is assumed from the data, 
reinforcing the magnitude and continuity of the problem.

Temporal analysis of leprosy is an important indicator of the health conditions of a region, State or country. In the case of Paraíba, the disease persists as relevant epidemiological dilemma, especially in view of the increase in the proportion of multibacillary cases, glimpsed for the studied period.

The results of this study can be used to help inform the healthcare services and public policy in achieving the goals advocated by the World Health Organization, which presents the pillar, among other things, of formulating strategies targeted to regional specificities, panorama which can be considered on the basis of the data submitted.

\section{References}

1. World Health Organization. Global Health Observatory Data Repository: Number of reported cases Data by country [Internet]. 2015 [cited 2015 Set. 06]. Available from: http://www.who.int/ lep/classification/en/

2. Penna MLF, Oliveira ML, Penna GO. The epidemiological behaviour of leprosy in Brazil. Lepr Rev. 2009; 80: 332-44.

3. Penna ML, Temporao JG, Grossi MA, Penna GO. Leprosy control: knowledge shall not be neglected. J Epidemiol Community Health. 2011; 65: 473-4

4. Organização Mundial da Saúde. Estratégia global aprimorada para redução adicional da carga da hanseníase (Período do plano: 2011-2015) [Internet]. 2010 [cited 2015 Set. 08]. Available from: http://bvsms.saude.gov.br/bvs/publicacoes/ estrategia global aprimorada reducao hanseniase.pdf

5. Penna MLF, Penna GO. Leprosy frequency in the world, 19992010. Mem Inst Oswaldo Cruz. 2012; 107(Suppl. I): 3-12.

6. World Health Organization. The final push towards elimination of leprosy: strategic plan 2000-2005 [Internet]. 2000 [cited 2015 Set. 08]. Available from: http://www.who.int/lep/resources/ Final Push \%20QA.pdf

7. Organização Mundial de Saúde. Estratégia Global para Aliviar a Carga da Hanseníase e Manter as Atividades de Controle da Hanseníase (Período do Plano: 2006-2010) [Internet]. 2005 [cited 2015 Set. 07]. Available from: http://www.saude.sp.gov. br/resources/ses/perfil/gestor/documentos-tecnicos/informestecnicos/estrategia global para controle de hanseniase.pdf
8. Brasil. Resolução $n^{\circ}$ 466, de 12 de dezembro de 2012. Dispõe sobre diretrizes e normas regulamentadoras de pesquisas envolvendo seres humanos. Diário Oficial da República Federativa do Brasil. Brasília: Ministério da Saúde; 2012.

9. Crespo MJ, Gonçalves A. Avaliação das possibilidades de controle da hanseníase a partir da poliquimioterapia. Rev Portuguesa de Saúde Pública. 2014; 32(1): 80-8.

10. WCS Smith. A Research Strategy to Develop New Tools to Prevent Leprosy, Improve Patient Care and Reduce the Consequences of Leprosy. Lepr Rev. 2012; 83(1): 6 - 15.

11. Gonçalves A. Realities of leprosy control: updating scenarios. Rev bras epidemiol. 2013; 16(3): 611-21.

12. Bobosha K, Tang ST, van der Ploeg-van Schip JJ, Bekele Y, Martins MV, Lund $O$, et al. Mycobacterium leprae virulenceassociated peptides are indicators of exposure to $\mathrm{M}$. leprae in Brazil, Ethiopia and Nepal. Mem Inst Oswaldo Cruz. 2012; 107(Suppl. I): 112-23.

13. Sarno EN, Duppre NC, Sales AM, Hacker MA, Nery JÁ, Matos HJ. Leprosy exposure, infection and disease: a 25-year surveillance study of leprosy patient contacts. Mem Inst Oswaldo Cruz. 2012; 107(8): 1054-9.

14. Ministério da Saúde. Secretaria de Vigilância em Saúde. Situação epidemiológica da hanseníase no Brasil: análise de indicadores selecionados na última década e desafios para eliminação. Bol Epidemiol [Internet]. 2013 [cited 2015 Set. 08]; 44(11): [about 12 p.]. Available from: http://portalsaude.saude.gov.br/images/ pdf/2014/junho/11/BE-2013-44--11----Hanseniase.pdf

15. World Health Organization. Global leprosy situation 2010. Weekly Epidemiol Rec [Internet]. 2010 [cited 2015 Set. 08]; 85: [about 11p.]. Available from: http://www.who.int/wer/2010/ wer8535.pdf?ua $=1$

16. World Health Organization. Global leprosy: update on the 2012 situation. Weekly Epidemiological Rec [Internet]. 2013 [cited 2015 Set 06]; 88(35): [about 15p.]. Available from: http://www. who.int/wer/2013/wer8835.pdf

17. Talhari S, Grossi MAF, Oliveira ML, Gontijo B, Talhari C, Penna GO. Hansen's disease: a vanishing disease?. Mem Inst Oswaldo Cruz. 2012; 107(Suppl. I): 13-6.

18. Lima HMN, Sauaia N, Costa VRL, Coelho Neto GT, Figueiredo PMS. Perfil epidemiológico dos pacientes com hanseníase atendidos em Centro de Saúde em São Luís, MA. Rev Bras Clin Med. 2010; 8(4):323-7.

19. Monteiro LD, Martins-Melo FR, Brito AL, Lima MS, Alencar $\mathrm{CH}$, Heukelbach J. Tendências da hanseníase no Tocantins, um estado hiperendêmico do Norte do Brasil, 2001-2012. Cad Saúde Pública. 2015 May; 31(5): 971-80

20. Corrêa RGCF, Aquino DMC, Caldas AJM, Amaral DKCR, França FS, Mesquita ERRBPL. Epidemiological, clinical, and operational aspects of leprosy patients assisted at a referral service in the state of Maranhão, Brazil. Rev Soc Bras Med. Trop. 2012 Feb; 45(1): 89-94. 
21. Araújo AERA, Aquino DMC, Goulart IMB, Pereira SRF, Figueiredo IA, Serra HO, et al. Neural complications and physical disabilities in leprosy in a capital of northeastern Brazil with high endemicity. Rev bras epidemiol. 2014 Out - dez; 17(4): 899-910.

22. World Health Organization. Leprosy elimination: Classification of leprosy. [cited 2015 Set 06]. Available from: http://www.who. int/lep/classification/en/

23. Xavier MB, Tavares NCS, Corrêa SC, Gonçalves BK, Ramos MMAB, Macedo GMM. Correlação entre as formas clínicas da hanseníase e o grau de incapacidade neurológica. Revista Paraense de Medicina. 2014; 28 (2).

24. Galvão PRS, Ferreira AT, Maciel MGG, Almeida RP, Hinders D, Schreuder PA, et al. Uma Avaliação do sistema de informação SINAN usado no Programa de Controle de Hanseníase no estado do Pernambuco, Brasil. Cad Saúde Coletiva. 2009; 17(1): 87-102.

25. Bovendorp ACC, Oliveira MB, Saleme PS, Lyon S, Bastos M. Qualidade de registros de hanseníase em centro de referência no estado de Minas Gerais, no período de 2006 a 2010. Rev Med Minas Gerais. 2014; 24(Supl 6): S61-5.

Publish in International Archives of Medicine

International Archives of Medicine is an open access journal publishing articles encompassing all aspects of medical science and clinical practice. IAM is considered a megajournal with independent sections on all areas of medicine. IAM is a really international journal with authors and board members from all around the world. The journal is widely indexed and classified Q1 in category Medicine. 